\title{
Deoxyribonucleic Acid Base Composition and Deoxyribonucleic Acid/Deoxyribonucleic Acid Hybrid Formation in Psjchrophobic and Related Yeasts
}

\author{
LEDA C. MENDONÇA-HAGLER ${ }^{1}$ AND HERMAN J. PHAFF \\ Department of Food Science and Technology, University of California, Davis, California 95616
}

\begin{abstract}
The deoxyribonucleic acid (DNA) base composition of several strains of the psychrophobic species Saccharomyces telluris, Torulopsis pintolopesii, T. bovina, and Candida slooffii was found to be similar, DNA/DNA hybridization experiments by means of the nitrocellulose filter technique revealed high degrees of homology between the nuclear DNAs of all four species. On the basis of these findings, $T$. bovina is considered to be a synonym of $T$. pintolopesii; $C$. slooffii, which has certain distinct and reproducible properties, was reclassified as $T$. pintolopesii var. slooffii. Saccharomycopsis guttulata has been retained as a separate species because its guanine plus cytosine value is higher than that of the four species mentioned above and it has other distinct properties. The nonpsychrophobic species Torulopsis glabrata was included for comparison. The guanosine plus cytosine content of its DNF. was approximately $7 \%$ higher than that of $T$. pintolopesii.
\end{abstract}

Psychrophobic enteric yeasts occur in the alimentary canal of certain domestic and wild animals (22). Such yeasts have minimum temperatures for growth ranging from approximately 20 to $30 \mathrm{C}$, whereas their maximum limits are somewhere between 40 and $46 \mathrm{C}$, depending on species and strain differences. Since a significant number of yeast species are known with similar maxima but with much lower minimal growth temperatures, the principal characteristic of psychrophobic yeasts is their rather high minimal temperature of growth. The species normally included in this group are Saccharomyces telluris (17) and its imperfect form Torulopsis bovina (21), $T$. pintolopesii $(18,21)$, Candida slooffii (19), and Saccharomycopsis guttulata (13). Species differentiation is based mainly on minimal temperature of growth and ability to form ascospores or pseudomycelia. In addition, some differences have been reported in nutritional requirements $(22,23)$ and in cell size. Very few carbon sources are utilized for growth, and the fermentative and assimilatory reactions are nearly identical. The salient properties of these species are shown in Table 1. Also included is Torulopsis glabrata, not a psychrophobic but a thermophilic species, which is sometimes associated with urinary tract infections in humans. This species superficially resembles the other organisms. It was included in this study for that reason and it also served as a control.

' Present address: Instituto de Microbiologia da Universidade Federal do Rio de Janeiro, G. B., Brazil.
Because of the many apparent similarities among these species, it was decided to study their deoxyribonucleic acid (DNA) base compositions on a comparative basis and to perform DNA/DNA reassociation experiments so that genetic relatedness could be evaluated between strains with similar base compositions. Several strains of each species were included in the survey.

\section{MATERIALS AND METHODS}

Organisms and growth conditions. The yeast strains designated IGC or CBS were obtained from the Instituto de Microbiologia of the Universidade Federal do Rio de Janeiro, Brazil. Their original sources are listed in Table 2. Yeasts were grown at $37 \mathrm{C}$ in a medium containing $1 \%$ proteose/peptone (Difco), $0.5 \%$ yeast extract (Difco), and $2 \%$ glucose. The $\mathrm{pH}$ was adjusted to 6.0. After $48 \mathrm{~h}$ of growth (beginning of stationary phase), cultures were inspected microscopically for bacterial contamination, after which the cells were harvested by centrifugation. Saccharomycopsis guttulata was cultivated for $24 \mathrm{~h}$ in a fermentor sparged with a mixture of air and $20 \%$ $\mathrm{CO}_{2}$ (4). In this medium, the yeast extract was replaced by $1 \%$ yeast autolysate (Albimi-Pfizer).

DNA extraction and purification. The DNA was extracted and purified by a combination of the procedures of Marmur (10) and Bernardi et al. (2). The yeast paste was suspended in sucrose buffer $[0.02$ M tris(hydroxymethyl)aminomethane-hydrochloride pH 7.8, $0.01 \mathrm{M}$ ethylenediaminetetraacetate $15 \%$ sucrose] to form a very thick suspension, after which the cells were broken in a Braun cell homogenizer (Bronwill Scientific, Inc.) operated at maximum speed for $1 \mathrm{~min}$ and cooled with liquid $\mathrm{CO}_{2}$. The 
TABLE 1. Differentiating characters among psychrophobic and thermophilic yeasts

\begin{tabular}{|c|c|c|c|c|c|c|c|}
\hline Species & $\begin{array}{c}\text { Asco- } \\
\text { spores } \\
\text { produced }\end{array}$ & $\begin{array}{l}\text { Pseudo- } \\
\text { mycelium }\end{array}$ & $\begin{array}{l}\text { Respir- } \\
\text { atory } \\
\text { ability }\end{array}$ & $\begin{array}{l}\text { Cell size }^{a} \\
\quad(\mu \mathrm{m})\end{array}$ & $\begin{array}{l}\text { Tempera- } \\
\text { ture range } \\
\text { for growth } \\
\text { (C) }\end{array}$ & $\begin{array}{l}\text { Assimila- } \\
\text { tion of } \\
\text { trehalose }\end{array}$ & $\begin{array}{l}\text { Require- } \\
\text { ment for } \\
\text { high con- } \\
\text { centration } \\
\text { of gaseous } \\
\mathrm{CO}_{2}\end{array}$ \\
\hline $\begin{array}{l}\text { Saccharomyces telluris van } \\
\text { der Walt } 1957\end{array}$ & $+c$ & - & + (weak) & $3.5-6.5$ by 4.5 to 8.5 & $20-22$ to 43 & - & - \\
\hline $\begin{array}{l}\text { Torulopsis bovina (van Uden } \\
\text { and do Carmo-Sousa) van } \\
\text { Uden and Vidal-Leiria } 1957\end{array}$ & $-c$ & - & + (weak) & $4-6$ by $6-9$ & $20-22$ to 43 & - & - \\
\hline T. pintolopesii van Uden 1952 & - & - & - & $2.5-3$ by $3-5$ & $24-42$ & - & - \\
\hline $\begin{array}{l}\text { Candia slooffii van Uden and } \\
\text { do Carmo-Sousa } 1957\end{array}$ & - & + & - & $4-7$ by $6-9$ & $28-46$ & - & - \\
\hline $\begin{array}{l}T \text {. glabrata (Anderson) Lod- } \\
\text { der and de Vries } 1917\end{array}$ & - & - & + & $2.5-4.5$ by $4-6$ & $6-43$ & + & - \\
\hline $\begin{array}{l}\text { Saccharomycopsis guttulata } \\
\text { (Robin) Schiönning 1853, } \\
\text { Synonymous with Cyni- } \\
\text { clomyces guttulatus (Ro- }\end{array}$ & + & + & + & $4.4-6.1$ by $14-21$ & $30-40$ & - or latent & + \\
\hline $\begin{array}{l}\text { bin) van der Walt and } \\
\text { Scott }\end{array}$ & & & & & & & \\
\hline
\end{tabular}

a Cells ( 1 to 3 days old) in glucose/yeast extract/peptone water.

'Data from references $13,17,19$, and 21 , except for the minimum temperature of growth for $T$. glabrata, which was determined in this study.

c + , Property present; -, property lacking.

TABLE 2. Yeast strains used in this study

\begin{tabular}{|c|c|c|}
\hline Species & Strain designations ${ }^{a}$ & Original sources \\
\hline Saccharomyces telluris & $\begin{array}{l}\text { IGC } 2622 \\
\text { CBS } 4055 \\
\text { CBS } 2676 \\
\text { CBS } 2679 \\
\text { IGC } 2663(=\text { CBS } \\
2685)^{b}\end{array}$ & $\begin{array}{l}\text { Mouse feces (Parle, New Zealand) } \\
\text { Cecum of horse } \\
\text { Excreta of rats and mice } \\
\text { Lung of pullet } \\
\text { Soil (van der Walt, South Africa) }\end{array}$ \\
\hline Torulopsis bovina & $\begin{array}{l}\text { CBS } 2760 \\
\text { IGC } 2678 \\
\text { IGC } 2681\end{array}$ & $\begin{array}{l}\text { Cecum of a cow } \\
\text { Crop of turkey } \\
\text { Cecal contents of a horse (van Uden, } \\
\quad \text { Portugal) }\end{array}$ \\
\hline$T \cdot$ pintolopesii & $\begin{array}{l}\text { CBS } 3046 \\
\text { IGC 2405 }(=\text { CBS } \\
\quad 1787) \\
\text { IGC } 2616 \\
\text { IGC } 2457\end{array}$ & $\begin{array}{l}\text { Mice injected with soil } \\
\text { Liver of a mouse } \\
\text { Unknown } \\
\text { Peritoneal cavity of a rat (Artagavey- } \\
\text { tia-Allende, Uruguay) }\end{array}$ \\
\hline Candida slooffii & $\begin{array}{l}\text { CBS } 2419^{b} \\
\text { IGC } 2687 \\
\text { IGC } 2689 \\
\text { CBS } 5040\end{array}$ & $\begin{array}{l}\text { Cecum of a horse } \\
\text { Cecum of a horse (van Uden, Portugal) } \\
\text { Cecum of a swine (van Uden, Portugal) } \\
\text { Frass of cossidae larvae (van der Walt, } \\
\quad \text { South Africa) }\end{array}$ \\
\hline$T$. glabrata & $\begin{array}{l}\text { UCD } 72-33 \\
\text { CBS } 4692 \\
\text { UCD } 72-28 \\
\text { UCD } 72-27\end{array}$ & $\begin{array}{l}\text { Gastric juice } \\
\text { Case of generalized mycosis } \\
\text { Peritoneal fluid (Ahearn, USA) } \\
\text { Sputum (Ahearn, USA) }\end{array}$ \\
\hline $\begin{array}{l}\text { Saccharomycopsis guttulata (synony- } \\
\text { mous with Cyniclomyces guttulatus) }\end{array}$ & UCD 73-90 & Domestic rabbit (Davis, California) \\
\hline
\end{tabular}

${ }^{a}$ Abbreviations: CBS, Centraal Bureau voor Schimmelcultures, Delft, Netherlands; IGC, Instituto Gulbenkian de Ciencios- LISBON, Portugal; UCD, University of California, Davis.

'Type strain. 
broken-cell suspension was diluted with a detergent solution containing $0.02 \mathrm{M}$ tris(hydroxymethyl)aminomethane-hydrochloride buffer, $\mathrm{pH} 7.8,0.01 \mathrm{M}$ ethylenediaminetetraacetic acid, $1 \%$ sodium lauryl sarcosate, and made to $1 \mathrm{M}$ sodium perchlorate. An equal volume of a mixture of chloroform/isoamyl alcohol $(24: 1, \mathrm{vol} / \mathrm{vol})$ was added, and the mixture was shaken at room temperature for $3 \mathrm{~h}$. The emulsion was then separated by centrifugation at $20,000 \times g$ for $20 \mathrm{~min}$. The aqueous upper layer was removed and chilled, and 1.3 volumes of cold ethanol were added. The precipitate was collected by centrifugation for $5 \mathrm{~min}$ at $5,000 \times \mathrm{g}$. The pellet was dissolved in $0.1 \times \mathrm{SSC}(\mathrm{SSC}=0.15 \mathrm{M} \mathrm{NaCl}, 0.015 \mathrm{M}$ sodium citrate, $\mathrm{pH} 7.0$ ), and the solution was made to $1 \times$ SSC. Pancreatic ribonuclease (Calbiochem) solution (boiled for $10 \mathrm{~min}$ ) and $\alpha$-amylase (Sigma Chemical Co.; Bacillus subtilis) solution were then added to final concentrations of $100 \mu \mathrm{g} / \mathrm{ml}$ each and placed at room temperature for $4 \mathrm{~h}$. This was followed by the addition of Pronase (nuclease free; Calbiochem) to a final concentration of $50 \mu \mathrm{g} / \mathrm{ml}$, and the solution was stored for $4 \mathrm{~h}$ at room temperature. The preparation was again extracted with chloroform/isoamyl alcohol for $30 \mathrm{~min}$ and separated as previously described. Ethanol was added to the aqueous phase, and the DNA was spooled out, dissolved in $1 \mathrm{mM}$ phosphate buffer at $\mathrm{pH} 6.8$, and dialyzed against the same buffer. The DNA was then puified by hydroxyapatite (Bio-Rad) chromatography. Proteins, carbohydrates, and ribonucleic acids (RNAs) were eluted with $0.15 \mathrm{M}$ phosphate buffer at $\mathrm{pH} 6.8$, and the DNA was eluted with $0.5 \mathrm{M}$ phosphate buffer at $\mathrm{pH} 6.8$. The absorbance at $260 \mathrm{~nm}\left(A_{280}\right)$ of the column eluate was monitored automatically with a model $2400 \mathrm{Gil}$ ford spectrophotometer. The ratios $A_{260} / A_{280}$ and $A_{230} / A_{260}$ of the samples containing peak absorbances were measured. Hydroxyapatite chromatography was repeated if the preparation showed a deviation of more than 0.05 from the ideal ratios: $A_{260} / A_{280}=1.86$ and $A_{230} / A_{260} 50.5$.

Labeling of DNA. DNA prepared as described above was labeled with ${ }^{125}$ I based on the procedure described by Commerford (6). Carrier-free ${ }^{125}$ I was obtained as $\mathrm{NaI}$ in $0.1 \mathrm{~N} \mathrm{NaOH}$ from New England Nuclear Corp., and thallium trichloride was obtained from $\mathrm{K} \& \mathrm{~K}$ Laboratories. Unlabeled DNA was sheared at $40,000 \mathrm{lb} / \mathrm{in}^{2}$ in a small French pressure cell made of titanium. Sheared, double-stranded DNA (50 to $150 \mu \mathrm{g}$ ) and 5 to $10 \mu \mathrm{Ci}$ of ${ }^{125} \mathrm{I}$ were used for labeling. The specific activities obtained varied between $10^{4}$ and $6 \times 10^{4} \mathrm{dpm} / \mu \mathrm{g}$ of DNA. Although there was a slight broadening of the DNA band in the ultracentrifuge, the quality of the DNA did not seem to be affected significantly.

Determination of guanine plus cytosine $(G+C)$ content. The methods of Schildkraut et al. (14) and Szybalski (15) were used for the determination of the buoyant densities of the DNA samples. Micrococcus lysodeikticus DNA was used as reference DNA, whose buoyant density was taken to be $1.7310 \mathrm{~g} / \mathrm{cm}^{3}$. Cesium chloride, code 62 , was purchased from the Rare Earth Division of American Potash and Chemical Corp. $M$. lysodeikticus DNA was obtained from Miles Labora- tories. Each DNA preparation was centrifuged at least four times in a Spinco analytical ultracentrifuge equipped with ultraviolet optics.

Preparation of DNA filters. DNA filters were prepared by the method of Gillespie and Spiegelman (8). Eight milliliters of an unlabeled, high-molecularweight DNA solution in $0.1 \times$ SSC $(50 \mu \mathrm{g} / \mathrm{ml})$ was denatured by heating to $100 \mathrm{C}$ for $10 \mathrm{~min}$ and quenched by pouring them into $72 \mathrm{ml}$ of ice-cold $6 \times$ SSC. The solution was filtered without vacuum through a $50-\mathrm{mm}$ BAC-T-Flex $\mathrm{B}_{6}$ Schleicher and Schull nitrocellulose filter presoaked with $6 \times$ SSC. The DNA was washed with $10 \mathrm{ml}$ of $6 \times \mathrm{SSC}$, and the filter was dried at room temperature overnight and then placed for $3 \mathrm{~h}$ in a vacuum oven at $80 \mathrm{C}$. About $90 \%$ of the DNA in solution was retained by the filter. Filters $10 \mathrm{~mm}$ in diameter were punched out of the larger filter, each one containing approximately $16 \mu \mathrm{g}$ of DNA, as determined by the Burton procedure (5). The small filters were then incubated for $3 \mathrm{~h}$ at $60 \mathrm{C}$ in the preincubation medium specified by Denhardt (7) to reduce background binding.

DNA/DNA duplex formation. Labeled, sheared DNA in $0.1 \times$ SSC used for duplex reactions was denatured by heating to $100 \mathrm{C}$ for $10 \mathrm{~min}$, after which it was poured into ice-cold $4 \times \mathrm{SSC}$ to give a final concentration of $2 \times \mathrm{SSC}$. The radioactive DNA solution was then added to vials containing the filters and incubated at $60 \mathrm{C}$ for $14 \mathrm{~h}$. The ratio of DNA on the filter to that in solution was approximately $30: 1$.

At the end of the incubation period, the filters were washed by two consecutive immersions in beakers containing about $200 \mathrm{ml}$ of $2 \times \mathrm{SSC}$ at $60 \mathrm{C}$. The filters were dried at room temperature and counted in a Packard Gamma model 578 scintillation spectrometer. Filters containing Escherichia coli DNA (and in one experiment calf thymus DNA) were used as controls to determine nonspecific binding. These control filter values were subtracted from the counts obtained with the yeast DNA. Relative binding was calculated as follows:

Relative binding

$=100 \times \frac{\mathrm{dpm} \text { of heterologous filters }}{\mathrm{dpm} \text { of homologous filters }}-\frac{\mathrm{dpm} \text { of control filters }}{-\mathrm{dpm} \text { of control filters }}$

Experiments showing 15 to $40 \%$ binding of the homologous, labeled input DNA to the homologous, unlabeled filter DNA were considered acceptable. One problem with ${ }^{125}$ I-labeled DNA is its erratic and often relatively high nonspecific binding (up to approximately $10 \%$ ). Only those experiments are reported in which the binding of labeled input DNA to control filters was not higher than 2 to $3 \%$.

All hybridizations were done in triplicate, by using one filter per vial. In general, the variation among the hybridization values was $\pm 5 \%$ (disintegrations per minute per filter); the values reported are averages for three filters. After the filters were counted, the residual DNA on the filters was determined by the Burton procedure (5) to establish losses due to leaching during incubation. If the filters lost more than $25 \%$ 
of the DNA originally placed on them, the values for hybridization were not used, and the experiment was repeated. Usually the loss was around 20 to $25 \%$ of the filter DNA.

\section{RESULTS}

Base composition of the DNAs. The mol\% $\mathrm{G}+\mathrm{C}$ of the DNA preparations of the organisms studied are listed in Table 3 . The results for the three strains of $C$. slooffii showed good agreement. Also, the DNAs of four strains of $T$. pintolopesii were similar in $\mathrm{G}+\mathrm{C}$ content. With one exception, the strains of $S$. telluris and its imperfect form $T$. bovina were all comparable in their DNA base composition. The exceptional strain, S. telluris IGC-2622, had a much higher mol\% $\mathrm{G}+\mathrm{C}$. The various $T$. glabrata strains showed good agreement among themselves; their $\mathrm{G}+\mathrm{C}$ levels were approximately $7 \%$ higher than those of the other species so far mentioned. Only one strain of $S$. guttulata, recently isolated in our laboratory, was studied. This organism is most difficult to maintain in laboratory cultures due to the very short life of the cells. Its $G+C$ content was somewhat higher than those of the other psychrophobic yeasts studied.

The most striking result was the similarity in $\mathrm{G}+\mathrm{C}$ values among the strains of $S$. telluris, $T$. bovina, $T$. pintolopesii, and $C$. slooffii (excluding the one with aberrant $\mathrm{G}+\mathrm{C}$ content). Thus the possibility was considered that these four species might represent simply morphological (ability to form pseudomycelium and cell size) or physiological (minimum temperature of growth) variants of a single taxon. To verify this hypothesis, DNA/DNA hybridizations were performed in various combinations.

Intraspecific hybridization of $\mathbf{C}$. slooffii DNAs. Table 4 shows the results obtained with the three $C$. slooffii strains investigated. Similar results were obtained with two species of labeled DNA. It is evident that the strains with an average of $32.37 \mathrm{~mol} \% \mathrm{G}+\mathrm{C}$ are representatives of the same species.

Intraspecific hybridization of $\mathrm{T}$. pintolopesii DNAs. Results from these experiments are shown in Table 5 . The four strains with an average base composition of $32.98 \pm 0.5 \mathrm{~mol} \%$ $\mathrm{G}+\mathrm{C}$ all demonstrated high degrees of relative binding of their DNAs with that of the reference strain no. 2616 (Table 5).

Intraspecific hybridization of $T$. bovina DNAs. The three strains with similar base compositions of 33.3 to $33.9 \mathrm{~mol} \% \mathrm{G}+\mathrm{C}$ (average 33.5 ) revealed high degrees of relative binding with the reference strains 2681 and 2678 (Table 6). In this case, an unrelated yeast
TABLE 3, DNA base compositions ( $m o l \% G+C$ ) of the strains studied based on buoyant density equilibrium centrifugations

\begin{tabular}{|c|c|c|c|}
\hline Species & Strains & $\begin{array}{l}\text { Buoyant } \\
\text { densities } \\
\left(\mathrm{g} / \mathrm{cm}^{3}\right)^{a}\end{array}$ & $\begin{array}{l}\text { Mol\% } \\
\mathbf{G}+\mathrm{C}\end{array}$ \\
\hline \multirow[t]{5}{*}{$\begin{array}{l}\text { Saccharomyces } \\
\text { telluris }\end{array}$} & IGC-2622 & $\begin{array}{c}1.6990 \pm 6 \\
\times 10^{-4}\end{array}$ & $39.8 \pm 0.6$ \\
\hline & CBS-4055 & $\begin{array}{c}1.6931 \pm 2 \\
\times 10^{-4}\end{array}$ & $33.8 \pm 0.2$ \\
\hline & CBS-2676 & $\begin{array}{c}1.6921 \pm 1 \\
\times 10^{-4}\end{array}$ & $32.8 \bullet 0.1$ \\
\hline & CBS-2679 & $\begin{array}{c}1.6925 \pm 2 \\
\times 10^{-}\end{array}$ & $33.2 \pm 0.2$ \\
\hline & IGC-2663 & $\begin{array}{c}1.6933 \pm 2 \\
\times 10^{-4}\end{array}$ & $34.0 \pm 0.2$ \\
\hline \multirow[t]{3}{*}{ Torulopsis bovina } & CBS-2760 & $\begin{array}{c}1.6926 \pm 1 \\
\times 10^{-4}\end{array}$ & $33.3 \pm 0.1$ \\
\hline & IGC-2678 & $\begin{array}{c}1.6926 \pm 1 \\
\times 10^{-4}\end{array}$ & $33.3 \pm 0.1$ \\
\hline & IGC-2681 & $\begin{array}{c}1.6932 \pm 3 \\
\times 10^{-4}\end{array}$ & $33.9 \pm 0.3$ \\
\hline \multirow[t]{4}{*}{ T.pintolopesii } & CBS-3046 & $\begin{array}{c}1.6928 \pm 1 \\
\times 10^{-4}\end{array}$ & $33.5 \pm 0.1$ \\
\hline & IGC-2405 & $\begin{array}{c}1.6921 \pm 1 \\
\times 10^{-4}\end{array}$ & $32.8 \pm 0.1$ \\
\hline & IGC-2616 & $\begin{array}{c}1.6924 \pm 2 \\
\times 10^{-4}\end{array}$ & $33.1 \pm 0.2$ \\
\hline & IGC-2457 & $\begin{array}{c}1.6919 \pm 4 \\
\times 10^{-4}\end{array}$ & $32.5 \pm 0.4$ \\
\hline \multirow[t]{3}{*}{ Candida slooffii } & CBS-2419 & $\begin{array}{c}1.6918 \pm 2 \\
\times 10^{-5}\end{array}$ & $32.4 \pm 0.02$ \\
\hline & IGC-2687 & $\begin{array}{c}1.6917 \pm 3 \\
\times 10^{-4}\end{array}$ & \\
\hline & IGC-2689 & $\begin{array}{c}1.6918 \pm 2 \\
\times 10^{-4}\end{array}$ & $32.4 \pm 0.2$ \\
\hline \multirow[t]{5}{*}{ T. glabrata } & & $\begin{array}{c}1.6994 \pm 4 \\
\times 10^{-4}\end{array}$ & \\
\hline & UCD $72-33$ & $\begin{array}{c}1.6990 \pm 5 \\
\times 10^{-4}\end{array}$ & $39.8 \pm 0.5$ \\
\hline & CBS-4692 & $\begin{array}{c}1.6994 \pm 4 \\
\times 10^{-4}\end{array}$ & $40.2 \pm 0.4$ \\
\hline & UCD $72-28$ & $\begin{array}{c}1.6990 \pm 5 \\
\times 10^{-4}\end{array}$ & $39.8 \pm 0.5$ \\
\hline & UCD $72-27$ & $\begin{array}{c}1.6988 \pm 4 \\
\times 10^{-4}\end{array}$ & $39.6 \pm 0.4$ \\
\hline $\begin{array}{l}\text { Saccharomycopsis } \\
\text { guttulata }\end{array}$ & UCD $73-90$ & $\begin{array}{c}1.6938 \pm 3 \\
\times 10^{-4}\end{array}$ & $34.5 \pm 0.3$ \\
\hline
\end{tabular}

${ }^{a}$ Average of four determinations.

control was included. This species, whose DNA contained $40.2 \mathrm{~mol} \% \mathrm{G}+\mathrm{C}$, revealed a very low degree of relative binding.

Intraspecific hybridization of $\mathrm{S}$. telluris DNAs. Three of the five strains (base compositions 32.8 to $34.0 \mathrm{~mol} \% \mathrm{G}+\mathrm{C}$ ) were used for this experiment. Significant duplex formation was observed between the reference strain and the two test strains (Table 7). Although the degree of relative binding of $S$. telluris strain 2676 DNA was somewhat lower than that observed in other 
TABLE 4. Degree of relative binding between various strains of Candida slooffii ${ }^{a}$

\begin{tabular}{c|c|c|c|c}
\hline $\begin{array}{c}\text { Unlabeled } \\
\text { filter DNA } \\
\text { from C. } \\
\text { slooffii } \\
\text { strain: }\end{array}$ & $\begin{array}{c}\text { dpm/filter } \\
\text { minus } \\
\text { control }^{b}\end{array}$ & $\begin{array}{c}\text { C. slooffii } \\
2687^{c}\end{array}$ & $\begin{array}{c}\text { dpm/filter } \\
\text { minus } \\
\text { control }^{d}\end{array}$ & $\begin{array}{c}\text { C. slooffii } \\
2689^{c}\end{array}$ \\
\hline 2419 & 1564 & $100.3^{e}$ & 440 & $98^{e}$ \\
2687 & 1558 & 100 & 420 & 94 \\
2689 & 1646 & 105 & 450 & 100 \\
\hline
\end{tabular}

a Incubation was at $60 \mathrm{C}$ for $14 \mathrm{~h}$.

- Control filter with $E$. coli DNA gave $200 \mathrm{dpm}$.

c $C$. slooffii 2687 and C. slooffii 2689 DNAs had specific activities of $2.5 \times 10^{4}$ and $1 \times 10^{4} \mathrm{dpm} / \mu \mathrm{g}$, respectively.

${ }^{d}$ Control filter with $E$. coli DNA gave $38 \mathrm{dpm}$.

e The results are expressed in percentages of the homologous reaction.

TABLE 5. Degree of relative binding between various strains of Torulopsis pintolepsii ${ }^{\circ}$

\begin{tabular}{c|c|c}
\hline $\begin{array}{c}\text { Unlabeled filter } \\
\text { DNA from } T . \\
\text { pintolopesii strain: }\end{array}$ & $\begin{array}{c}\mathrm{dpm} / \text { filter } \\
\text { minus control }\end{array}$ & $\begin{array}{c}\text { Labeled DNA } \\
\text { from } T \text {. pinto- } \\
\text { lopesii 2616 }\end{array}$ \\
\hline 3046 & 850 & $89^{d}$ \\
2405 & 940 & 99 \\
2616 & 950 & 100 \\
2457 & 900 & 95 \\
\hline
\end{tabular}

${ }^{a}$ Incubation was at $60 \mathrm{C}$ for $14 \mathrm{~h}$.

${ }^{b}$ Control filter with $E$. coli DNA gave $100 \mathrm{dpm}$.

c $T$. pintolopesii 2616 had a specific activity of $10^{4}$ $\mathrm{dpm} / \mu \mathrm{g}$.

$d$ The results are expressed in percentages of the homologous reaction.

combinations, we interpret the results of intraspecific binding as significant since unrelated yeasts normally give values close to $20 \%$ or lower (compare Table 6).

Interspecific hybridizations among $\mathbf{S}$. telluris, $T$. bovina, $T$. pintolopesii, and C. slooffii DNAs. The percentages of hybrid DNA formation are related to $T$. bovina 2678 or to $S$. telluris 2679 (Table 8). It is evident that the DNAs from all four species show high percentages of duplex formation as compared to the homologous reaction. It may, therefore, be concluded that the four species mentioned above are all members of a single taxon.

Intraspecific hybridization of $T$. glabrata DNAs. Although the DNA base compositions of the five strains tested (Table 9) were very close (range 39.6 to $40.2 \mathrm{~mol} \% \mathrm{G}+\mathrm{C}$ ), one of the strains (CBS 4692) gave a low degree of relative binding in comparison to the other four strains. Although the usual taxonomic criteria (21) were typical of this strain of $T$. glabrata, the colony morphology was atypical in that the surface was dull rather than soft and shiny. The low degrees of homology found suggest that this strain belongs to a species different from $T$. glabrata.

Since strain IGC-2622 of $S$. telluris had a DNA base composition very close to that of $T$. glabrata, this strain was included in the hybridization experiment. Strain IGC-2622 DNA showed no evidence of hybridization with $T$. glabrata 72-28 DNA although their base compositions were identical (Table 3). This aberrant strain was reidentified by the criteria discussed by van der Walt (16) and was shown to be a typical strain of Candida parapsilosis. The $\mathrm{G}+\mathrm{C}$ value found for this strain is in good agreement with values reported for $C$. parapsilosis in the literature (11). It is possible

TABLE 6. Degree of relative binding between various strains of Torulopsis bovina ${ }^{a}$

\begin{tabular}{c|c|c|c|c}
\hline \multirow{2}{*}{$\begin{array}{c}\text { Unlabeled filter } \\
\text { DNA from: }\end{array}$} & \multicolumn{4}{|c}{ Labeled DNA from } \\
\cline { 2 - 5 } & $\begin{array}{c}\mathrm{dpm} / \\
\text { filter } \\
\text { minus } \\
\text { control }\end{array}$ & $\begin{array}{c}T . \\
\text { bovina } \\
2681^{c}\end{array}$ & $\begin{array}{c}\text { dpm/ } \\
\text { filter } \\
\text { minus } \\
\text { control }\end{array}$ & $\begin{array}{c}T . \\
\text { bovina } \\
2678^{c}\end{array}$ \\
\hline T. bovina 2760 & 6271 & $87^{e}$ & 432 & 87 \\
2678 & 7222 & 100.2 & 496 & 100 \\
2681 & 7208 & 100 & & \\
$\begin{array}{c}\text { Saccharomyces } \\
\text { cerevisiae }\end{array}$ & 1441 & 20 & .74 & 15 \\
\hline
\end{tabular}

${ }^{a}$ Incubation was at $60 \mathrm{C}$ for $14 \mathrm{~h}$.

${ }^{\circ}$ Control filter with calf thymus DNA gave 500 dpm.

c $T$. bovina 2681 and $T$. bovina 2678 DNAs had specific activities of $5.5 \times 10^{4}$ and $1.6 \times 10^{4} \mathrm{dpm} / \mu \mathrm{g}$, respectively.

${ }^{d}$ Control filter with $E$. coli DNA gave $50 \mathrm{dpm}$.

${ }^{e}$ The results are expressed in percentages of the homologous reaction.

TABLE 7. Degree of relative binding between various strains of Saccharomyces telluris ${ }^{a}$

\begin{tabular}{c|c|c}
\hline $\begin{array}{c}\text { Unlabeled filter } \\
\text { DNA from } S . \\
\text { telluris strain: }\end{array}$ & $\begin{array}{c}\text { dpm/filter } \\
\text { minus control }\end{array}$ & $\begin{array}{c}\text { Labeled DNA } \\
\text { from } S . \\
\text { telluris } 2679^{c}\end{array}$ \\
\hline 2676 & 777 & $72^{d}$ \\
2679 & 1080 & 100 \\
2663 & 1004 & 93 \\
\hline
\end{tabular}

${ }^{a}$ Incubation was at $60 \mathrm{C}$ for $14 \mathrm{~h}$.

- Control filter with $E$. coli DNA gave $96 \mathrm{dpm}$.

${ }^{c} S$. telluris 2679 DNA had a specific activity of 1.6 $\times 10^{4} \mathrm{dpm} / \mu \mathrm{g}$.

${ }^{d}$ The results are expressed in percentages of the homologous reaction. 
TABLE 8. Degree of relative binding between strains of four psychrophobic species of yeast ${ }^{a}$

\begin{tabular}{|c|c|c|c|c|}
\hline \multirow[b]{2}{*}{$\begin{array}{l}\text { Unlabeled filter } \\
\text { DNA from: }\end{array}$} & \multicolumn{4}{|c|}{ Labeled DNA from: } \\
\hline & $\begin{array}{l}\text { dpm/ } \\
\text { filter } \\
\text { minus } \\
\text { control }^{b}\end{array}$ & $\begin{array}{c}T \\
\text { bovina } \\
2678^{r}\end{array}$ & $\begin{array}{l}\text { dpm/ } \\
\text { filter } \\
\text { minus } \\
\text { control }^{d}\end{array}$ & $\begin{array}{c}S \\
\text { telluris } \\
2679\end{array}$ \\
\hline $\begin{array}{l}\text { Candida slooffii } \\
\quad 2689\end{array}$ & 1169 & $95^{p}$ & & \\
\hline $\begin{array}{l}\text { Torulopsis pintolopesii } \\
\qquad \begin{array}{l}3046 \\
2457\end{array}\end{array}$ & 1193 & 97 & 4001 & 80 \\
\hline $\begin{array}{r}T . \text { bovina } 2760 \\
2678\end{array}$ & $\begin{array}{l}1045 \\
1230\end{array}$ & $\begin{array}{r}85 \\
100\end{array}$ & $\begin{array}{l}4000 \\
4252\end{array}$ & $\begin{array}{l}80 \\
85\end{array}$ \\
\hline $\begin{array}{l}\text { Saccharomyces telluris } \\
2676 \\
2679 \\
2663\end{array}$ & $\begin{array}{l}1242 \\
1143 \\
1142\end{array}$ & $\begin{array}{r}101 \\
93 \\
93\end{array}$ & 5000 & 100 \\
\hline
\end{tabular}

${ }^{a}$ Incubation done at $65 \mathrm{C}$ for $14 \mathrm{~h}$.

- Control filter with $E$. coli DNA gave $130 \mathrm{dpm}$.

c $T$. bovina 2678 and $S$. telluris 2679 DNAs had specific activities of $1.6 \times 10^{4}$ and $5 \times 10^{4} \mathrm{dpm} / \mu \mathrm{g}$, respectively.

${ }^{d}$ Control filter with $E$. coli DNA gave $430 \mathrm{dpm}$.

- The results are expressed in percentages of the homologous reaction.

that this strain was mislabeled while kept in the Brazilian culture collection.

\section{DISCUSSION}

The work reported here has shown that four recognized species of psychrophobic yeasts, which are all inhabitants of the alimentary canal of various warm-blooded animals (mammals and birds), are closely related by virtue of the similar base compositions and base sequences of their nuclear DNAs. This conclusion is based on the high percentages of heterologous DNA/DNA duplex formation as compared to homologous controls. Unrelated yeasts generally give DNA/DNA hybrid percentages around $20 \%$ or lower while closely related strains give values in the 80 to $100 \%$ range $(3,12)$. The data obtained here are in good agreement with these ranges.

It might be mentioned here that relatively few publications have appeared dealing with yeast systematics based on nucleic acid hybridization, and these are limited to the nitrocellulose filter disk technique. Therefore, brief mention of these methods with some comments on their advantages and disadvantages may be useful. Bak and Stenderup (1) used reciprocal binding to nitrocellulose filters, between in vitro-synthesized radiolabeled RNA (messenger RNA-like) and filter-bound nuclear (not whole- cell) DNA. The advantages of this method are: (i) no mitochondrial sequences are pressent; (ii) the in vitro labeling of messenger is simpler than in vivo labeling of nuclear DNA (but more laborious than in vitro labeling of DNA with ${ }^{125} \mathrm{I}$ ); and (iii) reciprocal binding experiments give excellent control over the data. On the other hand, a disadvantage of the method is the uncertainty that the entire genome is represented in RNA transcribed in vitro; some portions of the DNA may be selectively transcribed.

Bicknell and Douglas (3) performed DNA/ DNA and ribosomal RNA/DNA reannealing experiments on nitrocellulose filter disks by the competition technique; they used in vivo labeling of the required nucleic acids. The advantages of the method are: (i) uniform labeling of the nucleic acids; (ii) a greater portion of the genome is compared with competition than by direct binding; (iii) ribosomal RNA/DNA hybridization allows comparison of organisms which are not closely related because there is a significant degree of conservation of the genes coding for ribosomal RNA in different species of yeast. A disadvantage of this approach is the poor in vivo labeling of the DNA of a number of species with tritium or ${ }^{14} \mathrm{C}$-labeled bases, unless radiophosphorus with its rather short half-life is used. ${ }^{125}$ I is not only very inexpensive, but the in vitro labeling of DNAs from different yeasts was

TABLE 9. Degree of relative binding between strains of Torulopsis glabrata and other suspected strains of this species ${ }^{a}$

\begin{tabular}{|c|c|c|c|c|c|}
\hline \multirow{2}{*}{\multicolumn{2}{|c|}{$\begin{array}{l}\text { Unlabeled filter } \\
\text { DNA from: }\end{array}$}} & \multicolumn{4}{|c|}{ Labeled DNA from: } \\
\hline & & $\begin{array}{c}\text { dpm/ } \\
\text { filter } \\
\text { minus } \\
\text { |control }^{b}\end{array}$ & $\begin{array}{c}T . \\
\text { glabrata } \\
72-27^{\circ}\end{array}$ & $\begin{array}{c}\text { dpm/ } \\
\text { filter } \\
\text { minus } \\
\text { control }^{d}\end{array}$ & $\begin{array}{c}T . \\
\text { glabrata } \\
72-28\end{array}$ \\
\hline \multirow[t]{5}{*}{ T.glabrata } & 5040 & 5350 & $99^{\circ}$ & & \\
\hline & $72-33$ & 4486 & 83 & & \\
\hline & 4692 & 1405 & 26 & 764 & 21 \\
\hline & 72.28 & 4540 & 84 & 3637 & 100 \\
\hline & $72-27$ & 5404 & 100 & 3201 & 88 \\
\hline \multicolumn{2}{|c|}{ Saccharomyces tel } & & & 38 & 1 \\
\hline luris & 2622 & & & & \\
\hline
\end{tabular}

${ }^{a}$ Incubation was at $65 \mathrm{C}$ for $14 \mathrm{~h}$

${ }^{\circ}$ Control filter with $E$. coli DNA gave $350 \mathrm{dpm}$.

' $T$. glabrata $72-27$ and $T$. glabrata $72-28$ had specific activities of $2.5 \times 10^{4}$ and $1 \times 10^{4} \mathrm{dpm} / \mu \mathrm{g}$ of DNA, respectively.

${ }^{d}$ Control filter with $E$. coli DNA gave $280 \mathrm{dpm}$.

$e$ The results are expressed in percentages of the homologous reaction. 
quite reproducible and gave high counts. A disadvantage of this method is the need for a gamma ray counter.

Only one of the species, $S$. telluris, is ascogenous. T. bovina (synonymous with $C$. bovina) has been regarded as the imperfect stage of $S$. telluris (9), and the close relationship between these species has been confirmed in this study. $T$. pintolopesii and C. slooffii are differentiated from $S$. telluris ( $T$. bovina) by minor differences in cell size, by minimal growth temperatures, and by pseudomycelium formation (Table 1). When van Uden and do Carmo-Sousa (20) described $C$. bovina, they considered this species to be closely related to $T$. pintolopesii, described by van Uden five years earlier (18). They felt that using the ability of pseudomycelium formation to distinguish between organisms with very similar properties might lead to their artificial separation in different genera. Similarly, Kreger-van Rij (9), in her restudy of the various psychrophobic species, questioned the separation of $C$. bovina and $T$. pinolopesii, although she retained them provisionally as separate species.

Our work has now given clear evidence that all four species, i.e., S. telluris, T. bovina, T. pintolopesii, and $C$. slooffii, are representatives of the same taxon. The criterion of pseudomycelium formation is therefore of little or no value for species differentiation. The irrelevancy of pseudomycelium-forming ability in the diagnosis of species is supported by the earlier finding that Candida guilliermondii (with a welldeveloped pseudomycelium) revealed a high degree of DNA/DNA homology with $C$. guilliermondii var. carpophila, whose pseudomycelium-forming ability is either nonexistent or rudimentary (Sally A. Meyer, Ph.D. thesis, University of California, Davis, 1970). Relatively small variations in minimal growth temperature, which is the main criterion in differentiating these three imperfect yeasts (Table 1), also seem to be of doubtful taxonomic value for species differentiation. For example, Kregervan $\mathrm{Rij}$ (9) reported one strain of $S$. telluris which grew slowly at $25 \mathrm{C}$, but not at $20 \mathrm{C}$ as did other strains of this species. In general, variations in both minimal and maximal growth temperatures for strains of the same species have been observed by many investigators.

On the basis of this study, we are proposing to retain $S$. telluris and $T$. pintolopesii as the perfect and imperfect stages, respectively, of these psychrophobic yeasts. The name $T$. pintolopesii has priority over $T$. bovina (C. bovina) and C. slooffii.

Although the evidence presented here clearly shows that $C$. slooffii and $T$. pintolopesii are closely related and belong to the same species, we propose to retain $C$. slooffii as a variety of $T$. pintolopesii on the following grounds. Strains of C. slooffii are very homogeneous, unlike those of the other three "species." The minimal temperature of $C$. slooffii is $28 \mathrm{C}$ with a very short range of variation, while the minimal temperatures of strains of $T$. bovina, $S$. telluris, and $T$. pintolopesii may vary by as much as $5 \mathrm{C}$ (L. R. Travassos, personal communication). In contrast to the other species, $C$. slooffii has an absolute requirement for inositol, and requirements for other vitamins show almost no variation among strains. Furthermore, none of the other species showed a response to certain nutritional imbalances similar to that of $C$. slooffii (23). These characteristics, together with a more strongly developed pseudomycelium and a somewhat more restricted host range (swine and horses), induced us to retain $C$. slooffii as a variety of $T$. pintolopesii. Thus, $T$. pintolopesii var. slooffii differs from $T$. pintolopesii var. pintolopesii by having a minimal growth temperature of $28 \mathrm{C}$, by exhibiting an absolute requirement for inositol in Wickerham's medium, and by formation of pseudomycelium.

$T$. glabrata is clearly a distinct species. The $\mathrm{G}+\mathrm{C}$ content of its nuclear DNA is much higher than that of $T$. pintolopesii (Table 3), it is not a psychrophobic yeast (Table 1), and its cells are not short-lived in culture.

S. guttulata, on the other hand, has several features in common with the other psychrophobic organisms. Its principal points of difference are: (i) the small but significantly higher $\mathrm{G}+\mathrm{C}$ content of its nuclear DNA; (ii) its absolute requirement for a high concentration of gaseous $\mathrm{CO}_{2}$ in the environment; (iii) the very much larger vegetative cells; and (iv) the highly specific habitat in the intestinal tract of rabbits (13). It is possible that the psychrophobic species, now reduced to two ascosporogenous species and one asporogenous species, are derived from a common ancestor and have subsequently diverged by adapting to specialized habitats.

\section{ACKNOWLEDGMENTS}

We thank L. R. Travassos for critically reading the manuscript, and we are grateful for the capable technical assistance of Gayle Fuson.

The senior author was holder of a postdoctoral fellowship of the Brasilian National Research Council. This research was supported by Public Health Service grant GM-16307-05 from the National Institute of General Medical Sciences.

\section{REPRINT REQUESTS}

Address reprint requests to: Dr. Herman J. Phaff, Depart- 
ment of Food Science and Technology, University of California, Davis, Calif. 95616.

\section{LITERATURE CITED}

1. Bak, A. L., and A. Stenderup. 1969. Deoxyribonucleic acid homology in yeasts. Genetic relatedness within the genus Candida. J. Gen. Microbiol. 59:21-30.

2. Bernardi, G., M. Foures, G. Piperno, and P. P. Slonimski. 1970. Mitochondrial DNAs from respiratory-sufficient and cytoplasmic respiratory-deficient mutants of yeast. J. Mol. Biol. 48:23-42.

3. Bicknell, J. N., and H. C. Douglas. 1970. Nucleic acid homologies among species of Saccharomyces. J. Bacteriol. 101:505-512.

4. Buecher, E. J., and H. J. Phaff. 1970. Growth of Saccharomycopsis Schiönning under continuous gassing. J. Bacteriol. 104:133-137.

5. Burton, K. 1968. Determination of DNA concentration with diphenylamine, p. 163-166. In S. P. Colowick and N. D. Kaplan (ed.), Methods in enzymology, vol. 12. Academic Press Inc., New York.

6. Commerford, S. L. 1971. Iodination of nucleic acids in vitro. Biochemistry 10:1993-1999.

7. Denhardt, D. T. 1966. A membrane filter technique for the detection of complementary DNA. Biochem. Biophys. Res. Commun. 23:641-646.

8. Gillespie, D., and S. Spiegelman. 1965. A quantitative assay for DNA-RNA hybrids with DNA immobilized on a membrane. J. Mol. Biol. 12:829-842.

9. Kreger-van Rij, N. J. W. 1958. The relationship between Saccharomyces tellustris and Candida bovina. Antonie van Leeuwenhoek J. Microbiol. Serol. 24:137-144.

10. Marmur, J. 1961. A procedure for the isolation of DNA from microorganisms. J. Mol. Biol. 3:208-218.

11. Meyer, S. A., and H. J. Phaff. 1970. Taxonomic significance of the DNA base composition in yeast, p. 1-29. In D. G. Ahearn (ed.), Recent trends in yeast research, vol. 1. Spectrum (Georgia State University), Atlanta.

12. Meyer, S. A., and H. J. Phaff. 1972. DNA base composition and DNA-DNA homology studies as tools in yeast systematics, p. 375-387. In A. Kocková-Kratochvilová and E. Minarik (ed.), Yeasts-models in science and technics. Publishing House of the Slovak Academy of Sciences, Bratislava.

13. Phaff, H. J. 1970. Saccharomycopsis Schiönning, p. 725-732. In J. Lodder (ed.), The yeasts-a taxonomic study. North-Holland Publishing Co., Amsterdam.

14. Schildkraut, C. L., J. Marmur, and P. Doty. 1962. Determination of the base composition of deoxyribonucleic acid from its buoyant density in $\mathrm{CsCl}$. J. Mol. Biol. 4:430-433.

15. Szybalski, W. 1968. Use of cesium sulfate for equilibrium density gradient centrifugation, p. 330-360. In L. Grossman and K. Moldave (ed.), Methods in enzymol. ogy, vol. 12B. Academic Press Inc., New York.

16. van der Walt, J. P. 1970. Criteria and methods used in classification, p. 34-113. In J. Lodder (ed.), The yeasts-a taxonomic study. North-Holland Publishing Co., Amsterdam.

17. van der Walt, J. P. 1970. Saccharomyces Meyen emend. Reess., p. 555-718. In J. Lodder (ed.), The yeasts-a taxonomic study. North-Holland Publishing Co., Amsterdam.

18. van Uden, N. 1952. Zur Kenntnis von Torulopsis pintolopesii sp. nov. Arch. Mikrobiol. 17:199-208.

19. van Uden, N., and H. Buckley. 1970. Candida Berkhout, p. 893-1087. In J. Lodder (ed.), The yeasts-a taxonomic study. North-Holland Publishing Co., Amsterdam.

20. van Uden, N., and L. do Carmo-Sousa. 1957. Yeasts from the bovine caecum. J. Gen. Microbiol. 16:385-395.

21. van Uden, N., and M. Vidal-Leiria. 1970. Torulopsis Berlese, p. 1235-1308. In J. Lodder (ed.), The yeasts-a taxonomic study. North-Holland Publishing Co., Amsterdam.

22. Travassos, L. R., and A. Cury. 1971. Thermophilic enteric yeasts. Annu. Rev. Microbiol. 25:49-74.

23. Travassos, L. R., and L. C. Mendonça. 1972. Vitamin requirements and induced nutritional imbalances as criteria in speciating psychrophobic yeasts. Antonie van Leeuwenhoek J. Microbiol. Serol. 38:379-389. 